\title{
Competition Policy and Innovation in Developing Countries:
}

\section{Empirical Evidence}

\author{
George R.G. Clarke \\ A.R. Sanchez, Jr. School of Business, Texas A\&M International University \\ 5201 University Boulevard, Laredo, TX. 78041 \\ Tel: 1-956-326-2555 E-mail: George.Clarke@tamiu.edu
}

Received: May 11, 2011

Accepted: May 18, 2011

doi:10.5539/ijef.v3n3p38

\begin{abstract}
Firms in Eastern Europe and Central Asia that feel their competitors pressure them to innovate are more likely to innovate than firms do not. But price competition also reduces rents - and therefore the resources that firms have to invest. This paper assesses how competition policy affects these two different aspects of competition and how each affect innovation. It finds that enforcing competition law and cutting tariffs increases pressure to innovate and price competition. Because these affect innovation in opposite directions, it is not clear what competition policy's net impact will be. The empirical results in this paper suggest that stricter competition laws increase the likelihood that firms will introduce new products but decrease the likelihood that they will introduce new production processes. In contrast, lower tariffs modestly reduce new product and new process development.
\end{abstract}

Keywords: Competition law, Competition policy, Tariffs, Innovation, Eastern Europe, Central Asia

\section{Introduction}

It has long been recognized that competition might undermine innovation. Indeed, the patent system awards innovators temporary monopolies so that they can recoup their investment before rents are fully dissipated. But the patent system only protects innovations that are new to the world (i.e., that move the technology frontier) (Note 1). In developing economies, innovation is usually about working out how to produce existing goods profitably (i.e., approaching the innovation frontier) rather than developing entirely new goods (Acemoglu, Aghion, \& Zilibotti, 2006; Aghion \& Griffith, 2005; Hausmann \& Rodrik, 2003). As a result, patent protection will not protect most innovation in developing countries.

In the absence of patent protection, competition might undermine innovation, and therefore development. Rodrik (2004, p. 9), for example, argues:

When we put ourselves in the shoes of an entrepreneur engaged in cost discovery, we immediately see the key problem: this is an activity that has great social value and yet is poorly remunerated. If the entrepreneur fails in his venture, he bears the full cost of his failure. If he is successful, he has to share the value of his discovery with other producers who can follow his example and flock into the new activity. In the limit, with free entry, entrepreneurship of this kind produces private costs and social gains. It is no great surprise that low-income countries are not teeming with entrepreneurs engaged in self-discovery.

But others argue that competition is vital for innovation. For example, the World Bank's 2005 World Development Report argues that competition strengthens firm's incentives to innovate and estimates that competitive pressure could increase the probability that firms in developing countries innovate (World Bank, 2004, p. 15).

The empirical evidence for developing countries is mixed. Firms in low and middle-income countries in Eastern Europe and Central Asia that feel competitors pressure them to innovate are more likely to introduce new products and services than firms do not (Carlin, Fries, Schaffer, \& Seabright, 2004; World Bank, 2004). But firms in these countries that report that they face greater price competition from competitors are less likely to innovate than other firms (Carlin et al., 2004). That is, in some circumstances, competition appears to encourage innovation, while in others the pressure that competition puts on prices means that firms are less able to innovate. How much competition policy affects innovation will therefore depend on how much competition affects pressure from competitors and price competition.

This paper assesses the impact of competition policy on innovation using enterprise-level data from 27 low and middle-income countries in Europe and Central Asia. The paper extends the current literature by assessing how competition policy affects different aspects of competition as well as how these different aspects of competition affect 
product and process development. It concludes that there is some evidence that competition law might encourage new product development. But if trade policy has any effect on innovation in countries in this region, it is modest.

\section{Competition, Competition Policy and Innovation}

\section{The impact of competition policy in low and middle-income countries}

Although many government policies affect competition, competition law is the most direct way that governments do this. Although the goals, approach and scope of competition law vary between jurisdictions, the primary goal of most laws is to maintain and encourage competition and to prevent firms from gaining control of markets. As discussed in United Nations Conference on Trade and Development (2003), competition laws often include provisions that:

-

- $\quad$ Prevent single dominant firms from exercising market power.

- $\quad$ Require firms to notify the competition agency about mergers and allow the agency to investigate and prohibit mergers.

The transition economies of Eastern Europe and Central Asia have enthusiastically adopted competition laws. By 1999, all of the transition economies except Bosnia and Herzegovina and Turkmenistan had at least drafted competition laws (Dutz \& Vagliasindi, 2000; Vagliasindi \& Campbell, 2004).

Overall, the empirical literature on the effect that looks at whether competition law encourages competition yields mixed results. A cross-country study of competition law in 42 developed and developing countries found little evidence that competition law had a direct effect on prices; price markups were no lower in countries with competition laws in place than they were in other countries (Kee \& Hoekman, 2007). However, a second study that looked at the impact of competition policy in Eastern Europe and Central Asia concluded that enterprises were more likely to have competitors in countries where competition law was stronger and better enforced (Vagliasindi, 2001). One difference between these two papers, other than the choice of dependent variable, is that whereas the first simply uses a dummy variable indicating whether the country had a law or not, the second uses a broader measure that takes implementation into account.

There are several reasons why competition law might be ineffective, especially in low and middle-income countries (Note 2). One is that the agencies that enforce the laws in developing economies typically have fewer administrative and financial resources than agencies in industrialized economies (Note 3). A second problem is that it can be difficult to prosecute politically connected firms. For example, when the independent Monopoly Control Authority in Pakistan tried to take actions to reduce cartelization in the cement and vanaspati ghee markets, the government intervened, fixing prices at a 'mutually acceptable' level (CUTS Center for Competition, 2003). When government officials intervene against agency decisions on behalf of politically connected firms, competition agencies will be hesitant to move against these firms in the first place. This can be especially problematic in low and middle-income countries, which typically have weak institutional environments. Unless the agency can rely upon the judiciary to support its decisions and protect it against political intervention, the agency will find it difficult to enforce its rulings even if it is formally independent.

\section{The impact of other policies that affect competition.}

Competition law is not the only government policy that affects competition. Whereas competition law is generally intended to prevent firms from gaining control of markets, other government policies reduce competition. One notable way that governments reduce competition is by restricting access to foreign goods. Tariff and non-tariff barriers make it more costly for foreign firms to enter domestic markets and consequently reduce the competitive pressure on domestic firms. Many studies have found results that are consistent with the idea that trade restrictions reduce competition (see Tybout, 2003).

Another way that governments affect competition is by restricting entry. In some cases, for example when governments award legal monopolies, entry is simply prohibited. In other cases, the high cost of meeting regulatory requirements can reduce competition by making it difficult for new firms to enter. These barriers can reduce entry rates and thus competition. One study found that entry rates for new enterprises in several middle-income countries - none of whom had exceptionally high costs by developing country standards - would increase by as much as 20 percent if they reduced the cost of registering a business to the cost of doing so in the United States (Bartelsman, Haltiwanger, \& Scarpetta, 2004). To the extent that these barriers discourage entry, they will also reduce competition.

\section{The impact of competition on innovation in low and middle income countries}

In addition to depending upon the effectiveness of government policy in promoting competition, the effect of competition policy on innovation will depend upon the complex relationship between competition and innovation. Theoretical models do not unambiguously predict whether competition should encourage or discourage innovation, 
with different models predicting different effects (Note 4). One view is that competition is likely to encourage innovation. If firms in competitive industries fail to introduce new products or new technologies that reduce costs, nimbler competitors will force them out of the market. In contrast, firms with market power-especially those protected by government laws or regulations that make entry difficult and those that can protect their position by engaging in anticompetitive behavior - might not face the same risks if they fail to innovate.

Theoretical models that formalize these ideas often rely upon the concept of 'managerial slack.' Rather than simply maximizing profits, managers want to minimize effort. Although owners want to stop managers from slacking, this is easier in competitive industries since owners can compare the enterprise's performance with the performance of its competitors (Nickell, 1996). These ideas have been formalized in several theoretical models. For example, in a model with both managers whose goal is to minimize effort without going out of business (i.e., 'satisficing' managers) and profit-maximizing managers, Aghion, Dewatripont, \& Rey (1999) show that product market competition can encourage innovation (Note 5).

This is not the only way, however, that competition might affect innovation. The 'Schumpeterian' view is that firms will only innovate if they are able to recoup the cost of innovation by capturing monopoly rents. Indeed, this is the goal of patent protection; patents create temporary monopolies that allow innovative firms to exploit their ideas without having to compete with competitors who could otherwise would be able be able to expropriate their ideas (Note 6). To the extent that firms with market power have more stable and larger cash flows, they will find it easier to invest in new products and processes (Nickell, 1996).

Many of the new products and processes introduced by firms in these countries will be new to the firm rather than new to the market. Because so few patents are issued to firms in Eastern Europe and Central Asia, few of the products and processes introduced by the mostly small and medium-sized enterprises covered in this paper will be protected by patents (Note 7).

Some studies that have looked at the effect of competition on new product and process development and the results suggest a nuanced picture. On the one hand, pressure from other firms to develop new products, services and markets appears to be important. Firms that felt greater pressure, especially from foreign firms, to innovate were more likely to introduce new products and production processes than firms that felt less pressure (Carlin et al., 2004; World Bank, 2004). However, Carlin et al. (2004) also found that firms with greater market power were more likely to innovate. Thus, competition does not appear to have an unambiguous effect on innovation in low- and middle-income countries.

\section{Empirical Methods and Results}

Data

The data used in this study are from the 2002 Business Environment and Enterprise Performance Survey II (BEEPS II), an enterprise-level survey that covered 27 countries in Eastern Europe and Central Asia (Note 8). Although the survey included enterprises in all sectors of the economy, this paper focuses on is interested in the effect of both trade and competition policy, the sample used in this paper only includes manufacturing firms. The data from BEEPS II are supplemented with additional data collected by the World Bank. Tariff data is obtained from the UNCTAD TRAINS database.

Table 1 presents summary statistics for the main variables included in the empirical analysis.

\section{Econometric Approach}

To address the first question - the effect that competition policy and trade policy have on competition-we estimate the following equation:

Competition $_{i j k}=\delta_{1} \operatorname{Tariff}_{j k}+\delta_{2}$ Competition Policy $_{j}+\beta x_{i j k}+\gamma_{j}+\eta_{k}+\epsilon_{i j k}$

The competition indices represent how much competition firm $i$ in country $j$ and sector $k$ reports facing. Higher values represent greater competition. The three indices are:

- Index of Domestic Price Competition. This index represents that amount of domestic sales that the enterprise manager believes the firm would lose if it raised prices by 10 percent while its competitors did not (i.e., the elasticity of demand). A " 1 " on the 4-point scale means that the manager believes that the firm would not lose any sales, while a "4" means that many customers would buy from its competitors instead.

- Index of importance of pressure from foreign competitors on decisions concerning new products, services and markets. This index represents how great an impact foreign competitor has on decisions with respect to development of new products, services and markets. A " 1 " on the 4-point scale means that the manager feels that pressure from this source is 'not at all important', while a "4" means that they feel it is very important. 
- Index of importance of pressure from domestic competitors on decisions concerning new products, services and markets. As above, but for pressure from domestic competitors.

We focus on these indices because: (i) we would expect competition policy to have a direct effect on each measure; and (ii) previous work has shown that they are associated with innovation (Carlin et al., 2004; World Bank, 2004).

The indices take four distinct values. Since they are ordered rankings, but are not count data, the regressions are estimated as ordered probit regressions (i.e., assuming the error term, $\varepsilon_{\mathrm{ijk}}$, has a normal distribution). Because the error terms might be correlated for enterprises within the same country, standard errors might appear to be artificially small and t-statistics artificially large. To control for this, results are presented using Huber-White standard errors, allowing error terms to be correlated within countries (i.e., 'clustered' standard errors). (Note 9)

The main variables of interest are the tariff rate, tariff $_{j k}$, and measures of competition policy, competition policy $y_{j}$. The tariff rate is the average tariff for industry $\mathrm{j}$, defined at the 4-figure ISIC level, in country k. Unfortunately, comparable information was not available to calculate more sophisticated measures of trade protection (e.g., effective protection rates or measures that incorporate non-tariff barriers).

The measure of competition policy is an index that represents how strict merger notification laws are in the country calculated by Nicholson (2007). Higher values represent stricter laws (Note 10). The measure of 'barriers to entry' is the number of days to register a standardized business (World Bank, 2010). Since the competition policy variables are not available at the industry level, they are defined at the country level.

In addition to the main variables of interest, the analysis includes a small set of country controls $\left(\mathrm{z}_{\mathrm{j}}\right)$. Because we have data from only 27 countries, only a modest number of controls can be included: per capita GDP; size and population (to proxy for natural barriers to trade); and a dummy for countries in the Commonwealth of Independent States (to proxy for remoteness). Some specifications include country dummies rather than country controls.

In addition to these variables, the regressions also include a series of enterprise-level controls $\left(\mathrm{x}_{\mathrm{ijk}}\right)$. These include: number of workers (as a proxy for size), dummies indicating that the firm is foreign-owned, government owned or a de novo private enterprise (as opposed to a privatized enterprise), and a dummy indicating that the enterprise exports. A series of sector dummies - defined at the 4-figure ISIC level — are included to control for sector characteristics that might affect competition (Note 11).

\section{Econometric Results}

Table 2 shows results from regressions with and without country dummies. In the regressions with country dummies, variables that do not vary within countries (e.g., population, area, per capita GDP) drop out of the regression since they are collinear with the country dummies. Because the index of competition policy and days to register a business are both measured at the country level, these two variables are dropped when country dummies are included.

Competition law and barriers to entry. Enterprises were more likely to report that they would lose customers to competitors if they raised domestic prices by 10 percent and their competitors did not in countries with stricter competition laws (see column 1 of Table 2). This is consistent with the idea that competition laws promote competition. The coefficient on the competition law index is positive and statistically significant in the regression for the price competition index. The effect of having a merger notification law appears large. The average score on the price competition index would be 2.6 in countries with laws that require pre-merger notification compared with 2.2 in countries with no merger notification requirements (Note 12). Similarly, the average probability that an enterprise would say it would lose many of its customers if it raised prices is 18 percent in countries with no law, compared with 27 percent in countries with a pre-merger notification requirement.

Competition law might also affect the pressure that firms feel from both foreign and domestic enterprises. For example, a dominant firm that is able to maintain its position through marketing restrictions or control over distribution might be able to effectively prevent competition from both domestic and foreign firms. In the regression for pressure from foreign firms, the coefficient on the competition law index is positive and statistically significant (see column 3 of Table 2). This is consistent with the idea that pressure from foreign firms is greater in countries with stricter competition laws. The effect is more modest. The average score on the index for pressure from foreign firms would be 2.1 if all countries had no notification requirements and 2.4 if all countries had pre-merger requirements.

Although the coefficient on the competition law index is positive in the regression for pressure from domestic firms, it is statistically insignificant at conventional significance levels (see column 5). The point estimate also suggests a modest effect - the average score on the index for pressure from foreign firms would be 2.4 if all countries had no notification requirements and 2.7 if all countries had pre-merger requirements. 
The coefficient on the variable representing days to start a new business is negative in all regressions, suggesting that there is less competition in countries with significant barriers to entry. In all cases, however, the coefficients are statistically insignificant at conventional significance levels.

As a robustness check, we repeated the regressions with an alternative measure of competition law. The second index is taken from European Bank for Reconstruction and Development (2003) and represents the EBRD's assessment of competition policy and law in each country. In contrast to the measure above, which is based upon legal requirements, this measure takes enforcement into account (Note 13). For the most part the results are qualitatively similar, indicating that price competition and pressure to innovate from domestic competitors is greater in countries with stricter competition laws. The coefficient on the second index is statistically insignificant in the regression for pressure to innovate from foreign competitors (Note 14).

Average Tariff Rate. Enterprises were more likely to report that they would lose domestic sales to their competitors if they raised domestic prices by 10 percent and their competitors did not in countries where tariffs are lower. The coefficient on average tariff rates is statistically significant and negative whether country dummies or country controls are included in the regression (see columns 1 and 2 of Table 2).

The parameter estimates suggest that tariffs have a modest impact on domestic price competition. If tariffs were uniformly set at level of the $80^{\text {th }}$ percentile ( 18.3 percent), the average score would be 2.5 and the average probability that the firm would lose many customers if it raised its prices by 10 percent would be 26 percent. If tariffs were uniformly set at the level of the $20^{\text {th }}$ percentile ( 5 percent), the average score would be 2.7 and the average probability would be 31 percent. Increasing a uniform tariff from 5 percent to 18.3 percent would therefore reduce the probability that the average enterprise would lose many of its customers if it raised prices by 10 percent by 5 percentage points.

Tariffs also appear to affect pressure from foreign competitors (see columns 3 and 4). Enterprises were less likely to feel that pressure from foreign competitors had an important influence on their decisions to develop new products, services or markets in countries when tariffs were higher. The coefficient on the average tariff rate was statistically significant and negative when country dummies were included and negative, but statistically insignificant, when country controls are included. Overall these results suggest that firms feel less pressure from foreign firms in sectors and countries where tariff protection is high.

The impact is slightly smaller than the impact on domestic price competition. If tariffs were set at a uniform level of 5 percent (the $20^{\text {th }}$ percentile), the average score would be 2.4 and the average probability that the firms says pressure from foreign firms is an important influence on innovation would be 22 percent. If tariffs were set at a uniform level of 18.3 percent (the $80^{\text {th }}$ percentile), the average score would be 2.3 and the average probability would be 20 percent. Hence, increasing a uniform tariff from 5 percent to 18.3 percent would decrease the probability that the average enterprise would see pressure from foreign firms as an important influence by 2 percentage points.

Not surprisingly, tariffs do not appear to have a significant impact on the pressure that firms feel from domestic firms. The coefficient on average tariff rate is statistically insignificant in analogous regressions for pressure from domestic enterprises (see columns 5-6).

Other enterprise- and country-level controls. The coefficients on the country-level and enterprise-level controls are mostly statistically insignificant at conventional significance levels. For example, in the regression for the index of domestic price competition, the coefficients were statistically insignificant on all variables except for the dummy variable indicating that the firm is an exporter.

There were some exceptions to this rule, however. Large firms were more likely to say that pressure from foreign firms was important with respect to developing new products and services, but not more likely to report that domestic price competition was greater nor to report that pressure from domestic firms was important. Firms that were at least partially foreign-owned were less likely to report pressure from domestic competitors was important, as were firms that were at least partially state-owned. Finally de novo private firms were less likely to report that pressure from domestic enterprises was important.

Most exporters sell a significant portion of their output on domestic markets. The median exporter exported only about 35 percent of output and only 9 percent of exporters ( 5 percent of firms) exported all their output. Keeping this in mind, the results suggests that exporters feel less competitive pressure than other firms - at least in domestic markets. They were less likely to report that they would lose customers in domestic markets if they raised prices than non-exporters were. They were also less likely to report that they felt that pressure from domestic firms on their decisions to develop new products, services or markets. Because exporters tend to be more efficient and technologically advanced than non-exporters, it might not be surprising they generally feel less pressure from other domestic enterprises than non-exporters do. In contrast, exporters were more likely to report pressure from foreign firms than non-exporters 
were. Given that exporters are likely to compete with foreign firms in both domestic and international markets, this is not surprising.

\section{Impact on Innovation}

The previous results suggest that competition policy increases competition in Eastern Europe and Central Asia. Price competition and the pressure that firms feel to develop new products and services are greater in countries with stricter competition laws - suggesting that these laws successfully promote competition. Price competition and pressure from foreign firms regarding new products and services is also greater when tariffs are lower.

A natural question is whether this increased pressure increases the likelihood that firms introduce new products and processes. As noted earlier, although previous research has found that firms are more likely to innovate when they feel pressure from competitors (Carlin et al., 2004; World Bank, 2004), price competition appears to have the opposite effect(Carlin et al., 2004). The net impact of competition policy will therefore depend upon how much competition policy affects price competition and pressure from competitors and how much price competition and pressure from competitors affect innovation.

\section{Estimation}

To estimate the impact that pressure from foreign and domestic firms and price competition have on innovation, two dummy variables indicating whether between 1998 and 2001 the firm (i) introduced a major new product line and (ii) introduced a new technology that substantially changed the way it produces its main product are regressed on the competition indices from the previous section and a series on control variables.

$$
\text { Innovation }_{i j k}=\delta_{1} \text { Competition Indices }_{i j k+} \beta x_{i j k}+\gamma_{j}+\eta_{k}+\epsilon_{i j k}
$$

Since the dependent variables are dummy variables, the model is estimated using probit estimation. The coefficients presented in the tables are marginal effects for continuous independent variables (including the competition indices) and are the effect of switching the dummy from " 0 " to " 1 " for discrete variables. These effects are calculated at sample means for all variables.

One concern is that the competition indices tend to be highly correlated. The correlation between the two indices indicating pressure from foreign and domestic firms is 0.14 ( $\mathrm{p}$-value $=0.00$ ). Because of concerns about multicollinearity, we use principal components analysis to construct a single index for pressure from foreign and domestic firms. Because past work has indicated that pressure to innovate and price competition affect firms' decisions regarding innovation differently, we do not merge all three indices into a single measure of competition.

The control variables include a series of enterprise-level controls, a series of sector dummies (at the 4-figure ISIC level), and a series of countries dummies or country controls. As before, to control for the possibility that error terms might be correlated for enterprises within the same country, clustered standard errors are presented.

Results

Pressure from foreign and domestic enterprises. Consistent with earlier work, firms were more likely to introduce new production technologies and new product lines when they felt greater pressure to innovate. The coefficient on the index indicating pressure to innovate from foreign and domestic competitors is positive and statistically significant at a 1 percent level or higher in the regressions for the introduction of both new production processes (see column 1 in Table 3) and new products (see column 3). The positive coefficients suggests that firms that perceive that they are facing greater competitive pressure from competitors to innovate are, indeed, more likely to introduce new technologies and production processes. These results are robust to including country dummies rather than country controls (see column 2) (Note 15).

The impact of this pressure appears to be quite large. The estimate of the marginal effect (estimated at sample means) is 0.05 in the regression for new process development and 0.07 in the regression for new product development. This suggests that increasing the index for foreign firms by 1 point (on a four-point scale) would increase the probability that a firm introduced a new production technology between 1998 and 2001 by about 3 percentage points and increases the probability that the firm developed a new product line by about 4 percentage points (Note 16).

Although this might suggest that trade and competition policy might have a large effect on decisions regarding new products and technologies, it is important to keep in mind that a 1-point gain is much larger that the changes estimated in the previous section. Based upon the coefficients in the previous sections, decreasing tariffs from 18.3 percent to 5 percent (the $20^{\text {th }}$ percentile and $80^{\text {th }}$ percentile respectively) would increase the average score on the pressure from foreign competitors index by only about 0.06 points. Thus, cutting tariffs by this amount would increase the index of pressure by only about 0.04 points (Note 17). Based upon the coefficients in this section, cutting tariffs by this amount would increase the probability that an average firm would develop a major new product by only about 0.2 percentage 
points and that it would introduce a new production technology by only about 0.3 percentage points. Similarly, enacting a law that required pre-merger notification would increase the likelihood that the average enterprise would introduce a new process by 1.0 percentage points and a major new product by 1.4 percentage points.

Price Competition. The coefficient on the index for domestic price competition is statistically significant and negative in the regressions for new production processes (see column 1) and new products (see column 1). In contrast to the previous results, this suggests that this type of competition reduces, rather than increases, the likelihood of a firm introducing new products and processes. These results are also robust to including country dummies rather than country controls (see columns 2 and 4 ).

Cutting tariffs from 18.3 percent to 5 percent (the $20^{\text {th }}$ percentile and $80^{\text {th }}$ percentile respectively) would increase the average score on the index by only about 0.13 points. Thus, the coefficients in this section suggest that this would decrease the probability that an average firm would introduce new products and production technologies by only about 0.8 and 0.4 percentage points respectively. Similarly introducing a pre-merger notification requirement would decrease the average probabilities by 1.9 and 1.0 -percentage points respectively.

The net impact of changes in competition policy is, consequently, quite modest—although usually negative. Taking both effects into account, reducing tariffs from 18.3 percent to 5 percent would decrease the probability of new product and process development by 0.6 and 0.1 percentage points respectively. Introducing a pre-merger notification requirement would decrease the average probability of introducing a new process by 0.9 percentage points and increase the average probability of new product development by 0.5 percentage points (Note 18 ).

\section{Conclusion and Policy Recommendations}

Earlier empirical studies have shown that competition has an ambiguous effect on innovation in the low and middle-income economies of Eastern Europe and Central Asia. Although pressure from foreign and domestic competitors is positively associated with innovation (Carlin et al., 2004; World Bank, 2004), price competition appears negatively associated with it (Carlin et al, 2004). This paper assesses the net impact of changes in tariffs and competition laws on innovation by assessing the impact that these policies have on the different aspects of competition.

Firms in low and middle-income countries in Europe and Central Asia feel greater pressure to introduce new products and services and to enter new markets when tariffs are lower. Tariffs also affect firms' perceptions about market power. Firms were less likely to say that they believed they could raise prices by 10 percent without losing customers when tariffs were lower. Competition laws also affects competition in these countries. Firms were more likely to say that they felt pressure from competitors and were less likely to say that they could raise prices without losing customers in countries where competition law was stricter.

Because competition law is negatively associated with pressure to innovate from competitors (which is positively associated with innovation) and negatively associated with domestic price competition (which is negatively associated with innovation), the net impact on innovation will depend on the sizes of the opposing effects. Taking both into account, competition law appears to have a ambiguous impact on innovation. Firms in countries that required pre-merger notification were about 0.9 percentage points less likely to introduce new production processes but 0.5 percentage points more likely to introduce new products.

In contrast, the net impact of tariffs is negative but small — lower tariffs appear to be associated with less innovation. The point estimates of the parameters suggest that the average firm would be about 0.6 percentage points less likely to introduce a new production process and 0.1 percentage points less likely to introduce a new product if tariffs were set at a uniform 5 percent than if they were set at a uniform 18.3 percent. Given that about 43 percent of enterprises introduced new products and 57 percent introduced new production technologies between 1998 and 2001, this appears small.

\section{References}

Acemoglu, D., Aghion, P., \& Zilibotti, F. (2006). Distance to frontier, selection and economic growth. Journal of the European Economic Association, 4 (1), 37-74, doi:10.1162/154247606776014677, http://dx.doi.org/10.1162/154247606776014677.

Aghion, P., Dewatripont, M., \& Rey, P. (1999). Competition, financial discipline, and growth. Review of Economic Studies, 66 (4), 825-852, doi:10.1111/1467-937X.00110, http://dx.doi.org/10.1111/1467-937X.00110.

Aghion, P., \& Griffith, R. (2005). Competition and growth: Reconciling theory and evidence. Cambridge, MA: MIT Press. 
Bartelsman, E., Haltiwanger, J., \& Scarpetta, S. (2004). Microeconomics evidence of creative destruction in industrial and developing countries (Discussion Paper 1374). Bonn, Germany: Institute for the Study of Labor (IZA). Retrieved from http://ftp.iza.org/dp1374.pdf.

Carlin, W., Fries, S., Schaffer, M., \& Seabright, P. (2004). A minimum of rivalry: Evidence from transition economies on the importance of competition for innovation and growth. B.E.Journal of Economic Analysis and Policy: Contributions to Economic Analysis \& Policy, 3 (1), 1-43, doi:10.2202/1538-0645.1284, http://dx.doi.org/10.2202/1538-0645.1284.

CUTS Center for Competition. (2003). Pulling up our socks: A study of competition regimes of seven developing countries of Africa and Asia under the 7-UP project. Jaipur, India: Jaipur Printers. Retrieved from http://www.cuts-international.org/pulling.pdf.

Dutz, M., \& Vagliasindi, M. (2000). Competition policy implementation in transition economies: An empirical assessment. European Economic Review, 44 (4-6), 762-772, doi:10.1016/S0014-2921(99)00060-4, http://dx.doi.org/10.1016/S0014-2921(99)00060-4.

European Bank for Reconstruction and Development (2003). Transition report 2003: Integration and regional cooperation. London, UK: European Bank for Reconstruction and Development.

Fries, S., Lysenko, T., \& Polenac, S. (2003). The 2002 Business Environment and Enterprise Performance Survey: Results from a survey of 6100 firms (Working Paper 84). London UK: European Bank for Reconstruction and Development. Retrieved from http://www.ebrd.com/downloads/research/economics/workingpapers/wp0084.pdf.

Hausmann, R., \& Rodrik, D. (2003). Economic development as self-discovery. Journal of Development Economics, 72 (2), 603-633, doi:10.1016/S0304-3878(03)00124-X, http://dx.doi.org/doi:10.1016/S0304-3878(03)00124-X.

Huber, P.J. (1967). The behavior of maximum-likelihood estimates under non-standard conditions. In L.M.LeCam, \& J.Neyman (Eds.). Proceedings of the fifth Berkeley symposium in mathematical statistics and probability (pp. 221-233). Berkeley, CA: University of California Press.

Kee, H. L., \& Hoekman, B. (2007). Imports, entry, and competition law as market disciplines. European Economic Review, 51 (4), 831-858, doi:10.1016/j.euroecorev.2006.06.006, http://dx.doi.org/10.1016/j.euroecorev.2006.06.006.

Mansfield, E., Schwarz, M., \& Wagner, S. (1981). Imitation costs and patents: An empirical study. Economic Journal, 91 (364), 907-918, doi:10.2307/2232499, http://dx.doi.org/10.2307/2232499.

Nicholson, M. W. (2007). Quantifying antitrust regimes. Erasmus Law and Economics Review, 3 (1), 41-62, http://www.eler.org/index.php/eler/article/view/18.

Nickell, S. J. (1996). Competition and corporate performance. Journal of Political Economy, 104 (4), 724-746, doi:10.1086/262040, http://dx.doi.org/10.1086/262040.

Rodrik, D. (2004). Industrial policy for the twenty-first century (Discussion Paper 4767). London, UK: Center for Economic and Policy Research. Retrieved from http://www.cepr.org/pubs/new-dps/dplist.asp?dpno=4767.

Rogers, W. H. (1993). Regression standard errors in clustered samples. Stata Technical Bulletin Reprints, 3 (1), 88-94, http://www.stata.com/support/faqs/stat/stb13_rogers.pdf.

Schwab, K. (2010). The global competitiveness report 2010-2011. Geneva, Switzerland: World Economic Forum.

Tybout, J.R. (2003). Plant- and firm-level evidence on "new" trade theories. In E.K.Choi, \& J.Harrigan (Eds.). handbook of international trade (pp. 389-415). Malden, MA: Blackwell Publishers.

United Nations Conference on Trade and Development (2003). Model law on competition (Series on Issues in Competition Law and Policy TD/B/RBP/CONF.5/7/Rev.1). Geneva, Switzerland: United Nations Conference on Trade and Development. Retrieved from http://www.unctad.org/en/docs/tdrbpconf5d7.en.pdf.

Vagliasindi, M. (2001). Competition across transition economies: An enterprise-level analysis of the main policy and structural determinants (Working Paper 68). London UK: European Bank for Reconstruction and Development. Retreived from http://www.ebrd.com/downloads/research/economics/workingpapers/wp0068.pdf.

Vagliasindi, M., \& Campbell, L. (2004). Focus on competition law and policy: Enhancing enforcement and cooperation. Law in Transition, 2004 (1), 32-43, http://www.ebrd.com/downloads/research/law/lit041.pdf.

Vickers, J. (2010). Competition policy and property rights. Economic Journal, 120 (544), 375-392, doi:10.1111/j.1468-0297.2010.02360.x, http://dx.doi.org/10.1111/j.1468-0297.2010.02360.x.

White and Case LLP (2004). Worldwide antitrust merger notification requirements: The guide to 134 jurisdictions 2003-2004 edition. Washington DC: White and Case. 
World Bank. (2004). World development report 2005: A better investment climate for everyone. Washington DC: World Bank.

World Bank. (2010). Doing business 2011. Washington DC: World Bank.

\section{Notes}

* The data are from the Business Environment and Enterprise Performance survey (BEEPS II) OThe World Bank Group. I would like to thank Taye Mengestae for comments on an earlier draft and Warrick Smith and R. Shyam Khemani for helpful discussions. Responsibility for all the analysis, interpretations, and conclusions drawn from the data are entirely and solely those of the author. Responsibility for all errors and omissions rests solely with the author.

Note 1 . Several papers discuss the tension between competition policy and intellectual property rights protections. See, for example, Vickers (2010) and Aghion and Griffith (2005).

Note 2. The Global Competitiveness Report asked managers to rate the effectiveness of competition policy on a 7-point scale, where 1 means 'lax and not effective at promoting competition' and 7 means 'effective and promotes competition'. In 2010, the average score for the 91 low- and middle-income countries was 3.7, while the average score in high-income OECD countries was 4.9 (Schwab, 2010).

Note 3. For example, in 2000, the competition authority in Tanzania had only two economists and no lawyers, while the authority in Zambia had four economists and one lawyer (CUTS Center for Competition, 2003).

Note 4. See Aghion and Griffith (2005) for a discussion of theoretical models related to competition and innovation.

Note 5. Aghion and Griffith (2005) test several models of managerial slack and find some evidence consistent with theory and other evidence inconsistent with theory.

Note 6. Mansfield, Schwarz, \& Wagner (1981) finds that, on average, it cost imitating firms $65 \%$ of the cost of innovation to imitate new products.

Note 7. According to data from the U.S. Patent and Trademark Office, only about 655 patents were granted to firms and individuals in any of the 27 countries in Eastern Europe and Central Asia in 2010. In comparison, about 44,814 were granted to firms and individuals in Japan and 12,363 to the same in Germany.

Note 8. The BEEPS II survey is described in Fries, Lysenko, \& Polenac (2003).

Note 9. See Huber (1967) and Rogers (1993).

Note 10. The index is coded as " 0 " if the country has no merger notification law, coded as " 1 " if merger notification is voluntary, coded as " 2 " if post-merger notification is mandatory, and " 3 " if pre-merger notification is mandatory. Information on notification laws was obtained from White and Case (2004)

Note 11. As a robustness check, we also looked at the effect of ouliers by winsoring the continuous variables in the regressions in Table 2 and Table 3. For the most part, the results were similar to the unwinsorized results. The results in 3 were virtually unchanged. For Table 2, the results on the main variables were similar although the coefficient on tariffs becamse statistically insignificant in the regression on foreign pressure with country dummies (i.e., column 3). The coeffiicent on the competition law index became statistically significant at a 5 percent level in the regression for domestic pressure (column 5) and the significance level on this variable fell to 11 percent in the similar regression for foreign pressure.

Note 12. These comparisons are made by estimating fitted values setting the index equal to " 0 " (no merger notification) and then doing the same setting the index equal to "3" (pre-merger notification mandatory) for all firms in the sample.

Note 13. For example, the 2003 Transition report states '[t]he classification system is a stylized reflection of the judgment of the EBRD's Office of the Chief Economist.' See European Bank for Reconstruction and Development(2003).

Note 14. Results are available upon request.

Note 15. The results are also robust to including the two indices for pressure from foreign and domestic firms simultaneously rather than the first principal component. The coefficients on both indices are positive and statistically significant at a 10 percent level or higher. Results available on request

Note 16. A one-point increase in the foreign pressure index would increase the combined index by about 0.62 points.

Note 17. The estimates from the principal component analysis indicate that a one-point increase on the foreign pressure index increases the principal component index by 0.62 points and a one-point increase on the domestic pressure index increases the principal component index by 0.68 points. 
Note 18. Increasing the score on the competition policy index would decrease the average probability of new process development by 0.1 percentage points and increase the average probability of new product development by 0.5 percentage points. We also experimented with other model specifications. Most notably, we included several additional measures of competition (number of competitors, market share) and allowed the competition indices to affect innovation non-linearly by including a squared term. The results were similar to the results in Table 3 .

Table 1. Sample means and standard deviations.

\begin{tabular}{|c|c|c|c|c|}
\hline & Variable & Obs. & Mean & Std. Dev. \\
\hline \multicolumn{5}{|l|}{ Technology } \\
\hline Developed major new product in past 3 years & Dummy & 1626 & 0.43 & 0.49 \\
\hline Introduced new production technology & Dummy & 1625 & 0.57 & 0.50 \\
\hline \multicolumn{5}{|l|}{ Competition Indices } \\
\hline Index of price competition & Index $(0-4)$ & 1621 & 2.56 & 1.08 \\
\hline Pressure from foreign competitors & Index $(0-4)$ & 1576 & 2.35 & 1.14 \\
\hline Pressure from domestic competitors & Index $(0-4)$ & 1606 & 2.70 & 1.04 \\
\hline \multicolumn{5}{|l|}{ Competition Policy } \\
\hline Average Tariff Rate (4-figure ISIC) & --- & 1518 & 13.49 & 14.47 \\
\hline Competition Law Index & Index $(0-3)$ & 1516 & 2.57 & 1.03 \\
\hline Days to Register a New Business & Natural Log & 1584 & 3.70 & 0.46 \\
\hline \multicolumn{5}{|l|}{ Country Controls } \\
\hline Population & Natural Log & 1633 & 16.37 & 1.30 \\
\hline Area in Squared Kilometers & Natural Log & 1542 & 12.27 & 1.77 \\
\hline Per Capita GDP & Natural Log & 1633 & 7.53 & 0.85 \\
\hline Commonwealth of Independent States & Dummy & 1633 & 0.42 & 0.49 \\
\hline \multicolumn{5}{|l|}{ Enterprise Controls } \\
\hline Workers & Natural Log & 1565 & 4.08 & 1.66 \\
\hline Any Government Ownership & Dummy & 1633 & 0.19 & 0.39 \\
\hline Any Foreign Ownership & Dummy & 1633 & 0.21 & 0.41 \\
\hline De novo private enterprise & Dummy & 1633 & 0.53 & 0.50 \\
\hline Exporter & Dummy & 1626 & 0.51 & 0.50 \\
\hline
\end{tabular}


Table 2. Impact of trade and competition policy in competition

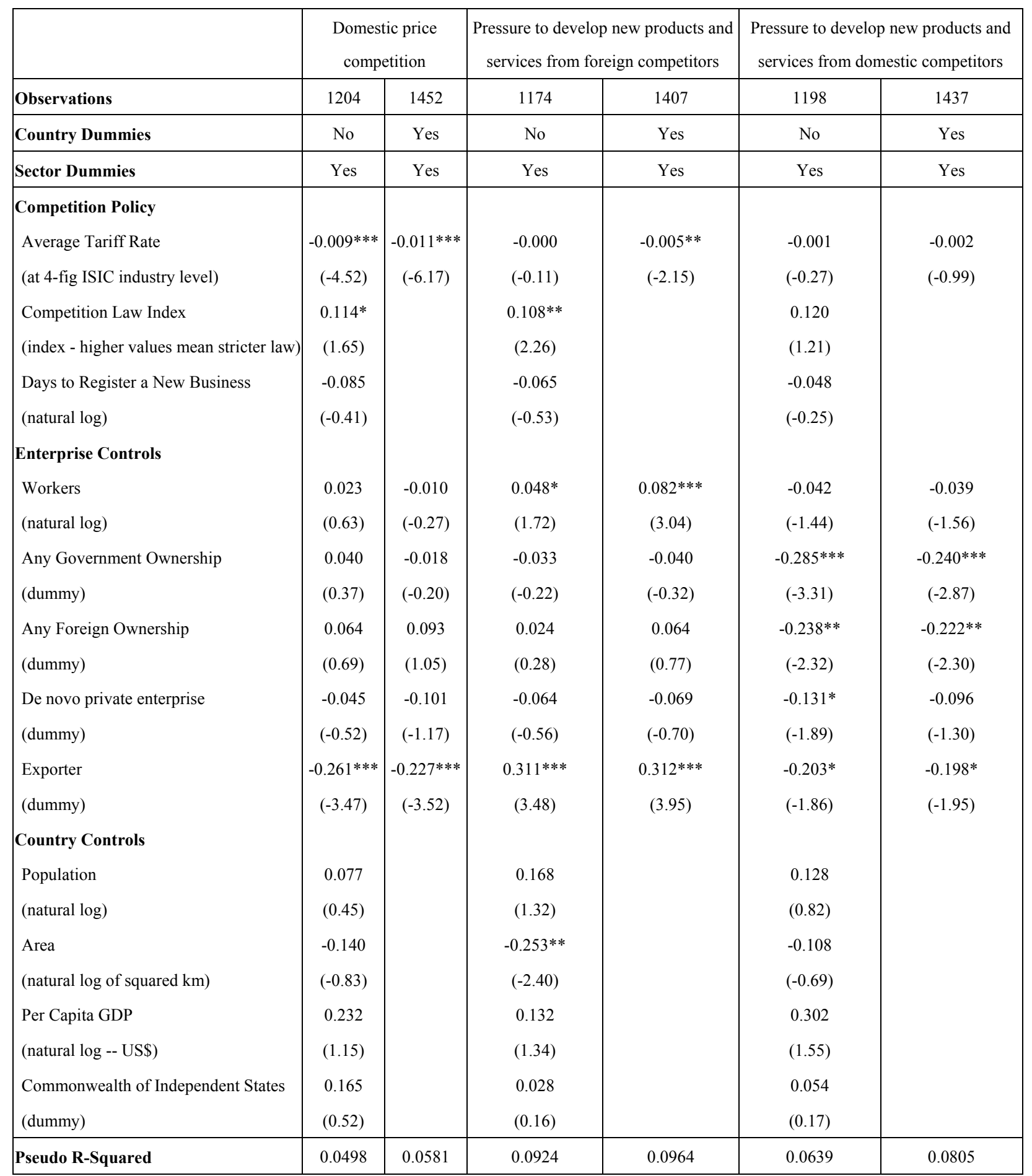

*** Sig. at $1 \%$ level ** Sig. at $5 \%$ level * Sig. at $10 \%$ level. Note: High values of competition indices mean more competition. Regressions are estimated using ordered probit estimation. T-statistics are in parentheses. Standard errors are Huber-White robust standard errors allowing error terms to be correlated within countries. Regressions include dummy variables indicating country and sector of operations (at 4-figure ISIC level). 
Table 3. Impact of Competition on New Product and Process Development

\begin{tabular}{|c|c|c|c|c|}
\hline \multirow[b]{2}{*}{ Observations } & \multicolumn{2}{|c|}{$\begin{array}{l}\text { New Product Development } \\
\text { (Dummy) }\end{array}$} & \multicolumn{2}{|c|}{$\begin{array}{l}\text { New Process Development } \\
\text { (Dummy) }\end{array}$} \\
\hline & 1394 & 1500 & 1399 & 1505 \\
\hline Country Dummies & No & Yes & No & Yes \\
\hline Sector Dummies & Yes & Yes & Yes & Yes \\
\hline \multicolumn{5}{|l|}{ Competition } \\
\hline $\begin{array}{l}\text { Index of pressure from foreign and domestic competitors } \\
\text { (index - high values mean more competition) }\end{array}$ & $\begin{array}{c}0.051^{* * *} \\
(3.52)\end{array}$ & $\begin{array}{c}0.054 * * * \\
(3.47)\end{array}$ & $\begin{array}{c}0.071 * * * \\
(4.91)\end{array}$ & $\begin{array}{c}0.062^{* * *} \\
(4.12)\end{array}$ \\
\hline Index of price competition & $-0.061^{* * *}$ & $-0.066^{* * *}$ & $-0.031^{* *}$ & $-0.041 * * *$ \\
\hline (index - high values mean more competition) & $(-5.93)$ & $(-7.19)$ & $(-2.07)$ & $(-3.08)$ \\
\hline \multicolumn{5}{|l|}{ Enterprise Controls } \\
\hline Workers & $0.031 * * *$ & $0.036^{* * *}$ & $0.065 * * *$ & $0.060 * * *$ \\
\hline (natural log) & $(2.65)$ & $(3.12)$ & $(5.77)$ & $(5.01)$ \\
\hline Any Government Ownership & $-0.095^{* *}$ & $-0.091 * *$ & $-0.156^{* * *}$ & $-0.148 * * *$ \\
\hline (dummy) & $(-2.00)$ & $(-2.25)$ & $(-3.08)$ & $(-2.83)$ \\
\hline Any Foreign Ownership & -0.024 & -0.018 & -0.019 & -0.027 \\
\hline (dummy) & $(-0.60)$ & $(-0.48)$ & $(-0.46)$ & $(-0.74)$ \\
\hline De novo private enterprise & $0.080^{*}$ & $0.074 *$ & $0.154 * * *$ & $0.159^{* * *}$ \\
\hline (dummy) & $(1.79)$ & $(1.75)$ & $(3.97)$ & $(3.99)$ \\
\hline Exporter & $0.059^{* *}$ & 0.032 & $0.109 * * *$ & $0.123^{* * *}$ \\
\hline (dummy) & $(2.00)$ & $(1.19)$ & $(2.89)$ & $(2.97)$ \\
\hline \multicolumn{5}{|l|}{ Country Controls } \\
\hline Population & 0.029 & & -0.043 & \\
\hline (natural log) & $(0.75)$ & & $(-1.08)$ & \\
\hline Area & $-0.058 * * *$ & & 0.020 & \\
\hline (natural log of squared km) & $(-2.66)$ & & $(0.72)$ & \\
\hline Per Capita GDP & -0.013 & & -0.055 & \\
\hline (natural log -- US\$) & $(-0.60)$ & & $(-1.11)$ & \\
\hline Commonwealth of Independent States & $0.087 *$ & & 0.149 & \\
\hline (dummy) & $(1.88)$ & & $(1.54)$ & \\
\hline Pseudo R-Squared & 0.09 & 0.11 & 0.12 & 0.16 \\
\hline
\end{tabular}

Note: T-statistics are in parentheses. Standard errors are Huber-White robust standard errors allowing error terms to be correlated within countries. Regressions include dummy variables indicating country and sector of operations (at 4-figure ISIC level). Regressions include sector dummies (at 4-figure ISIC level) and country dummies (columns 2 and 4) 